\title{
Analysis of Sound Translation of Indonesian Names in the Chinese Newspaper Harian Indonesia (Yinni Xingzhou Ribao)
}

\author{
Rosella Hasyim ${ }^{1}$, Pauw Budianto ${ }^{2}$
}

Universitas Kristen Maranatha, Bandung, Indonesia

Universitas Kristen Maranatha, Bandung, Indonesia

\begin{tabular}{|c|c|}
\hline Article History & Abstract \\
\hline $\begin{array}{c}\text { Submitted date: } \\
\text { 2021-07-30 } \\
\text { Accepted date: } \\
\text { 2021-10-04 } \\
\text { Published date: } \\
\text { 2021-11-28 } \\
\text { Keywords: } \\
\text { Chinese language; } \\
\text { Indonesian names; sound } \\
\text { translation; newspaper }\end{array}$ & $\begin{array}{l}\text { In the process of learning Mandarin, Indonesian names are often found transliterated } \\
\text { into Mandarin. In this research, the writer discuss Indonesian names which are } \\
\text { transliterated into Mandarin. This study discuss the classification of the translation of } \\
\text { the sounds of Indonesian names and the rules of translating the sounds of Indonesian } \\
\text { names into Chinese which are presented in the Chinese newspaper Harian Indonesia. } \\
\text { This study used descriptive qualitative method to describe the rules in translating the } \\
\text { sounds of Indonesian names along with their classification. This research used literature } \\
\text { review technique to collect the data. From this study, the results of the analysis } \\
\text { regarding the classification of Indonesian names and the rules in translating the sound } \\
\text { of Indonesian names in the Mandarin newspaper Harian Indonesia were obtained. This } \\
\text { research is expected to help Indonesian students who study Mandarin and to increase } \\
\text { knowledge of the translation of the sounds of Indonesian names in Mandarin and the } \\
\text { classification of the translation of the sounds of Indonesian names. }\end{array}$ \\
\hline & Abstrak \\
\hline \multirow{2}{*}{$\begin{array}{l}\text { Kata Kunci: } \\
\text { bahasa Mandarin; nama } \\
\text { Indonesia; penerjemahan } \\
\text { bunyi; surat kabar }\end{array}$} & $\begin{array}{l}\text { Analisis Penerjemahan Bunyi Nama Indonesia pada Surat Kabar Mandarin } \\
\text { Harian Indonesia (Yinni Xingzhou Ribao) }\end{array}$ \\
\hline & $\begin{array}{l}\text { Pada proses pembelajaran bahasa Mandarin sering kali ditemukan nama Indonesia yang } \\
\text { ditransliterasikan ke dalam bahasa Mandarin. Pada penelitian ini penulis akan } \\
\text { membahas nama Indonesia yang ditransliterasikan ke dalam bahasa Mandarin. } \\
\text { Penelitian ini membahas pengelompokan penerjemahan bunyi nama Indonesia dan } \\
\text { mengetahui kaidah-kaidah dalam penerjemahan bunyi nama Indonesia ke dalam bahasa } \\
\text { Mandarin yang disajikan pada surat kabar Mandarin Harian Indonesia. Penelitian ini } \\
\text { menggunakan metode deskriptif kualitatif untuk menjabarkan kaidah-kaidah dalam } \\
\text { penerjemahan bunyi nama Indonesia beserta pengelompokannya. Penelitian ini } \\
\text { menggunakan teknik pengumpulan data studi pustaka. Dari penelitian ini didapatkan } \\
\text { hasil analisis mengenai pengelompokan nama Indonesia serta kaidah-kaidah dalam } \\
\text { penerjemahan bunyi nama Indonesia pada surat kabar Mandarin Harian Indonesia. } \\
\text { Penelitian ini diharapkan dapat membantu para pelajar Indonesia yang mempelajari } \\
\text { bahasa Mandarin dalam memahami dan menambah pengetahuan akan penerjemahan } \\
\text { bunyi nama Indonesia dalam bahasa Mandarin dan pengelompokan penerjemahan } \\
\text { bunyi nama Indonesia. }\end{array}$ \\
\hline
\end{tabular}

Corresponding author:

${ }^{1}$ rosellahsym8@gmail.com 
Hasyim, R., \& Budianto, P., (2021). Analysis of Sound Translation of Indonesian Names in the Chinese Newspaper (Yinni Xingzhou Ribao). LITE: Jurnal Bahasa, Sastra, dan Budaya 17 (2), 160-175. https://doi.org/10.33633/lite.v17i2.5044

\section{Pendahuluan}

Manusia hidup dalam keberagaman. Terdapat berbagai macam keberagaman, salah satunya adalah keberagaman bahasa. Bahasa adalah alat yang digunakan untuk berkomunikasi dengan individu lain dan merupakan sebuah karakteristik yang dimiliki oleh suatu negara atau bangsa.

Bahasa Mandarin merupakan salah satu bahasa yang paling berpengaruh di dunia. Pengaruh bahasa Mandarin tersebut dapat dilihat salah satunya di Indonesia, contohnya adalah adanya surat kabar dan acara televisi berbahasa Mandarin. Dalam surat kabar maupun acara televisi berbahasa Mandarin selalu ditemukan nama asing dan nama Indonesia yang ditransliterasikan ke dalam bahasa Mandarin. Transliterasi adalah metode penerjemahan yang umum digunakan dan juga merupakan cara yang umum untuk menyerap kata-kata asing. Transliterasi sering digunakan untuk menerjemahkan nama orang, nama tempat, dan istilah baru. Oleh karena itu, kata benda seperti nama orang dan nama tempat serta kata-kata baru dalam bahasa asing sering diserap melalui transliterasi (Chen Shunyi, 2014: 93-96).

Dalam mempelajari kata-kata asing kita tidak hanya dapat memahami peran yang mereka mainkan dalam perkembangan bahasa Mandarin, tetapi juga membantu untuk mengeksplorasi situasi pertukaran etnis dan budaya dalam sejarah perkembangan kebangsaan Han (Zhang Yu, 2011). Namanama yang ditransliterasikan ke dalam bahasa Mandarin sering kali didasarkan pada bunyi atau makna dari nama tersebut. Transliterasi nama asing tersebut menekankan kedekatan atau kesamaan bunyi, dan tidak menekankan ekspresi semantik kecuali bentuk bunyi (Wu Liquan, 2018: 7-15).

Pada penelitian ini penulis menganalisis nama Indonesia yang ditransliterasikan ke dalam bahasa Mandarin. Oleh karena itu, penulis mengangkat judul penelitian yang berjudul Analisis Penerjemahan Bunyi Nama Indonesia pada surat kabar Mandarin Harian Indonesia (Yinni Xingzhou Ribao). Alasan penulis memilih judul penelitian tersebut adalah karena penerjemahan bunyi nama Indonesia ke dalam bahasa Mandarin merupakan salah satu hal yang penting dalam penerjemahan. Adanya penerjemahan nama Indonesia tersebut dapat mempermudah warga Tiongkok untuk memahami nama Indonesia. Nama-nama Indonesia yang ditransliterasikan ke dalam bahasa Mandarin tersebut memiliki bunyi dan cara pelafalan yang berbeda. Transliterasi ke dalam bahasa Mandarin meniru bunyi dari kata asing, mencoba untuk membuat bunyi bahasa asing dan bahasa Mandarin semirip mungkin (Liu Xiangqing, 2021: 23-27).

Dalam menerjemahkan nama terdapat beberapa strategi yang dapat digunakan. Menurut Pour terdapat empat strategi penerjemahan nama diri, yaitu menuliskan kembali nama sesuai dengan nama dalam bahasa sumber, transkripsi dan transliterasi, substitusi, dan penerjemahan nama jika nama mengandung makna (Suhardi et al., 2019: 1-16). Terdapat 4 strategi penerjemahan nama diri, yaitu menyalin (copy) adalah strategi penerjemahan tanpa perubahan ejaan, menyesuaikan (adaptation) adalah strategi penerjemahan dengan adanya penyesuaian ejaan dan bunyi, mengganti (substitution) adalah strategi penerjemahan dengan adanya perubahan, dan diterjemahkan (translated) adalah strategi penerjemahan dengan menerjemahkan nama yang mengandung arti (Hermans, 1988: 13).

Penelitian terdahulu mengenai penerjemahan bunyi nama laki-laki orang Indonesia pernah dilakukan oleh Simanto (2013) dalam skripsinya membahas penerjemahan bunyi nama laki-laki ke dalam bahasa Mandarin berdasarkan tinjauan fonetik bahasa Indonesia dan diterjemahkan berdasarkan suku kata. Perbedaan penelitian penulis dengan penelitian tersebut adalah penelitian yang dilakukan oleh penulis menjabarkan pengelompokan nama Indonesia dan kaidah-kaidah penerjemahan bunyi nama Indonesia pada surat kabar Mandarin Harian Indonesia (Yinni Xingzhou Ribao) yang mencakup mengenai fonem vokal, fonem konsonan, diftong, dan suku kata. Bahan penelitian yang digunakan oleh penulis mencakup nama orang, kota, tempat dan lainnya dengan menggunakan teknik analisis data berupa pengelompokan dan perbandingan. 
Hasyim, R., \& Budianto, P., (2021). Analysis of Sound Translation of Indonesian Names in the Chinese Newspaper (Yinni Xingzhou Ribao). LITE: Jurnal Bahasa, Sastra, dan Budaya $17 \quad$ (2), $160-175$. https://doi.org/10.33633/lite.v17i2.5044

Penulis memilih nama Indonesia sebagai bahan untuk diteliti karena nama-nama Indonesia baik itu nama orang, kota, tempat dan lainnya selalu muncul dalam berita yang disajikan di surat kabar, majalah dan televisi berbahasa Mandarin. Selain itu, nama-nama Indonesia yang ditransliterasikan ke dalam bahasa Mandarin memiliki bunyi dan cara pelafalan yang sama, mirip, atau berbeda. Penulis memilih surat kabar Mandarin Harian Indonesia (Yinni Xingzhou Ribao) sebagai sumber data dengan pertimbangan surat kabar Mandarin Harian Indonesia (Yinni Xingzhou Ribao) merupakan salah satu surat kabar yang memuat berita harian baik dari dalam negeri maupun luar negeri dengan menggunakan bahasa Mandarin. Oleh karena itu, nama asing dan nama Indonesia yang ditransliterasikan ke dalam bahasa Mandarin sering muncul pada surat kabar tersebut.

Artikel ini bertujuan untuk (1) mengetahui pengelompokan penerjemahan bunyi nama Indonesia yang disajikan pada surat kabar Mandarin Harian Indonesia (Yinni Xingzhou Ribao), dan (2) mengetahui kaidah-kaidah dalam penerjemahan bunyi nama Indonesia ke dalam bahasa Mandarin pada surat kabar Mandarin Harian Indonesia (Yinni Xingzhou Ribao).

\section{Metode}

Pada penelitian ini penulis menggunakan metode deskriptif kualitatif. Metode deskriptif kualitatif digunakan penulis untuk menjabarkan pengelompokan penerjemahan bunyi nama Indonesia serta menjabarkan kaidah-kaidah dalam penerjemahan bunyi nama Indonesia ke dalam bahasa Mandarin. Penelitian ini menggunakan pendekatan kualitatif dikarenakan data-data yang diperoleh berupa tulisan yang berasal dari surat kabar, serta penemuan hasil dari penulisan ini tidak dapat dilakukan dengan menggunakan data-data berupa statistik. Teknik analisis data yang digunakan adalah pengelompokan dan perbandingan.

\section{Hasil dan Pembahasan}

\subsection{Pengelompokan Penerjemahan Bunyi Nama Indonesia Berdasarkan Strategi Penerjemahan Nama}

Berdasarkan 4 strategi penerjemahan nama yang dikemukakan oleh Hermans (1988), penulis mengelompokkan nama Indonesia yang ditransliterasikan ke dalam bahasa Mandarin sebagai berikut:

Tabel 1: Tabel Pengelompokan

\begin{tabular}{|c|c|c|c|c|c|}
\hline No & Nama Indonesia & $\begin{array}{l}\text { Nama Indonesia dalam Bahasa } \\
\text { Mandarin }\end{array}$ & Menyalin & Menyesuaikan & Mengganti \\
\hline 1 & I Wayan Koster & $\begin{array}{l}\text { 伊.瓦延.科斯特 } \\
\text { yi | wa-yan | ke-si-te }\end{array}$ & $\sqrt{ }$ & $\sqrt{ }$ & \\
\hline 2 & Jokowi & $\begin{array}{l}\text { 佐科威 } \\
\text { zuo-ke-wei }\end{array}$ & & $\sqrt{ }$ & \\
\hline 3 & Salima & $\begin{array}{l}\text { 萨利玛 } \\
\text { sa-li-ma }\end{array}$ & $\sqrt{ }$ & & \\
\hline 4 & Pontianak & $\begin{array}{l}\text { 坤甸 } \\
\text { kun-dian }\end{array}$ & & & $\sqrt{ }$ \\
\hline 5 & Solo & $\begin{array}{l}\text { 梭罗 } \\
\text { suo-luo }\end{array}$ & & $\sqrt{ }$ & \\
\hline 6 & Rumah Sakit Parepare & $\begin{array}{l}\text { 巴列巴列医院 } \\
\text { ba-lie-ba-lie yiyuan }\end{array}$ & & $\sqrt{ }$ & \\
\hline 7 & Mandalika & $\begin{array}{l}\text { 曼达利卡 } \\
\text { man-da-li-ka }\end{array}$ & $\sqrt{ }$ & & \\
\hline 8 & Bandara Ahmad Yani & $\begin{array}{l}\text { 阿赫马德·雅尼机场 } \\
\text { a-he-ma-de | ya-ni jichang }\end{array}$ & $\sqrt{ }$ & $\sqrt{ }$ & \\
\hline 9 & Batamindo & $\begin{array}{l}\text { 峇塔民多 } \\
\text { ba-ta-min-duo }\end{array}$ & & $\sqrt{ }$ & \\
\hline 10 & Musim mas & $\begin{array}{l}\text { 穆西姆马斯 } \\
\text { mu-xi-mu-ma-si }\end{array}$ & & $\sqrt{ }$ & \\
\hline
\end{tabular}


Hasyim, R., \& Budianto, P., (2021). Analysis of Sound Translation of Indonesian Names in the Chinese Newspaper (Yinni Xingzhou Ribao). LITE: Jurnal Bahasa, Sastra, dan Budaya 17 (2), 160-175. https://doi.org/10.33633/lite.v17i2.5044

\begin{tabular}{|c|c|c|c|c|c|}
\hline No & Nama Indonesia & $\begin{array}{l}\text { Nama Indonesia dalam Bahasa } \\
\text { Mandarin }\end{array}$ & Menyalin & Menyesuaikan & Mengganti \\
\hline 11 & Bahana & $\begin{array}{l}\text { 岑哈纳 } \\
\text { ba-ha-na }\end{array}$ & $\sqrt{ }$ & & \\
\hline 13 & Universitas Nitra & $\begin{array}{l}\text { 尼特拉大学 } \\
\text { ni-te-la daxue }\end{array}$ & & $\sqrt{ }$ & \\
\hline 14 & Kali Malang & $\begin{array}{l}\text { 卡利玛琅 } \\
\text { ka-li-ma-lang }\end{array}$ & $\sqrt{ }$ & & \\
\hline 15 & Avanza & $\begin{array}{l}\text { 阿梵萨 } \\
\text { a-fan-sa }\end{array}$ & & $\sqrt{ }$ & \\
\hline
\end{tabular}

Penerjemahan bunyi nama Indonesia baik itu nama orang, kota, tempat, perusahaan dan lainnya sebagian besar termasuk ke dalam penerjemahan bunyi dengan strategi menyesuaikan (adaptation). Pada nama dalam bahasa Indonesia, kata-kata di atas sebagian besar termasuk ke dalam penerjemahan bunyi dengan strategi menyesuaikan (adaptation). Hal ini dikarenakan adanya perbedaan pelafalan huruf-huruf dan terdapat beberapa aturan dalam bahasa Mandarin, salah satunya adalah konsonan dalam bahasa Mandarin yang tidak dapat berdiri sendiri.

Beberapa nama Indonesia yang termasuk ke dalam penerjemahan bunyi dengan strategi menyalin (copy) dan beberapa nama Indonesia yang ditransliterasikan ke dalam bahasa Mandarin merupakan penerjemahan nama dengan strategi gabungan menyalin dan menyesuaikan. Sebagian kecil nama Indonesia termasuk ke dalam penerjemahan bunyi nama Indonesia dengan strategi mengganti (substitution). Tujuan adanya transliterasi kata-kata dari bahasa asing ke dalam bahasa Mandarin adalah transliterasi mencoba untuk membuat orang merasa bahwa kata itu tidak asing (Wu Liquan, 2018: 50-61). Aksara transliterasi adalah hasil perekaman bunyi kata atau suku kata asing dengan aksara Han yang bunyinya mirip dalam bahasa Mandarin (Liu Xiangqing, 2013: 87-90, 114). Nama dan nama tempat juga pada saat ditransliterasikan ke dalam bahasa Mandarin harus mengikuti bunyi yang terdekat, mudah diingat dan menghindari adanya gagasan negatif (Zhu \& Liu, 2020: 39-42).

Transliterasi bahasa Mandarin berbeda dengan transliterasi lainnya, karena terdapat perbedaan yang besar antara bahasa Mandarin dengan bahasa Barat. Bahasa Mandarin dan bahasa Barat memiliki standar yang berbeda, pembentukannya didasarkan pada aksara Han dan suku kata. Meskipun pada akhirnya semua suku kata dapat dianalisis sebagai fonem, fonem tidak memiliki bentuk penulisan sendiri dalam aksara Han, hanya bisa meminjam suku kata dalam aksara Han untuk menjelaskannya (Liu Xiangqing, 2019: 92-96). Pengucapan bahasa Mandarin dan bahasa Barat tidak sama persis, hal ini yang menjadi alasan mendasar mengapa transliterasi sulit akurat (Lian \& Dai, 2012: 132-136). Sama halnya, bahasa Indonesia dan bahasa Mandarin memiliki bunyi yang berbeda.

\subsection{Aksara Han yang Digunakan pada Penerjemahan Bunyi}

\subsubsection{Fonem Vokal}

Fonem Vokal

- $/ \mathrm{a} / \rightarrow$ 阿 $a$

Fonem /a/ ditransliterasikan ke dalam bahasa Mandarin dengan menggunakan aksara Han 阿, contohnya:

阿古斯·古米旺 (a-gu-si | gu-mi-wang) = Agus Gumiwang

阿霖 (a-lin)

$$
=\text { Alin }
$$

- $/ y a / \rightarrow$ 亚ya

$\rightarrow$ 娅 $y a$

$\rightarrow$ 雅 $y a$ 
Hasyim, R., \& Budianto, P., (2021). Analysis of Sound Translation of Indonesian Names in the Chinese Newspaper (Yinni Xingzhou Ribao). LITE: Jurnal Bahasa, Sastra, dan Budaya $17 \quad$ (2), $160-175$. https://doi.org/10.33633/lite.v17i2.5044

Fonem /a/ menghasilkan bunyi [ya] saat dilafalkan, saat ditransliterasikan ke dalam bahasa Mandarin digunakan aksara Han dengan pinyin ya. Umumnya terjadi pada fonem /a/ yang berdampingan dengan fonem /i/ dan fonem /y/, contohnya:

拉迪蒂亚 (la-di-di-ya) = Raditya

阿莉雅 $(\mathrm{a}-\mathrm{-li}-\mathrm{ya}) \quad=$ Alia

娜娜. 尤莉娅娜 (na-na | you-li-ya-na) = Nana Yuliana

- $/ 0 / \rightarrow$ 奥 $a o$

Fonem /o/ saat ditransliterasikan ke dalam bahasa Mandarin menggunakan aksara Han 奥, contohnya:

苏迪奥诺 (su-di-ao-nuo) = Sudiono

- $/ \mathrm{e} / \rightarrow$ 埃 $a i$

Fonem /e/ saat ditransliterasikan ke dalam bahasa Mandarin menggunakan aksara Han 埃, contohnya:

埃迪.帕拉勃沃 (ai-di | pa-la-bo-wo) = Edi Prabowo

- $/ \mathrm{i} / \rightarrow$ 伊 $y i$

Fonem /i/ dan fonem /y/, keduanya menghasilkan bunyi [i], saat ditransliterasikan ke dalam bahasa Mandarin menggunakan aksara Han 伊, contohnya:

伊万·达尔利安 (yi-wan $\mid$ da-er-li-an) = Iwan darlian

博伊·拉弗利 (bo-yi | la-fu-li) = Boy Rafli

- $/ \mathrm{u} / \rightarrow$ 乌 $w u$

Fonem /u/ saat ditransliterasikan ke dalam bahasa Mandarin menggunakan aksara Han 乌, contohnya:

乌米 $($ wu-mi $)=\mathbf{U m i}$

3.2.2 Diftong

/ai/ $\rightarrow$ 爱 $a i$

$\rightarrow$ 埃 $a i$

爱尔朗加大学 (ai-er-lang-jia daxue)

埃都耳.阿兹哈利 (ai-du-er | a-zi-ha-li)

= Universitas Airlangga

= Aidul Azhari

Diftong /ai/ dalam bahasa sumber memiliki bunyi yang sama dengan aksara Han 埃 dan 爱.

\subsubsection{Fonem Konsonan}

\begin{tabular}{|c|c|c|c|c|c|}
\hline Fonem & $\begin{array}{c}\text { Bunyi } \\
\text { dalam } \\
\text { Bahasa } \\
\text { Indonesia }\end{array}$ & $\begin{array}{c}\text { Bunyi } \\
\text { dalam } \\
\text { Bahasa } \\
\text { Mandarin }\end{array}$ & $\begin{array}{l}\text { Aksara Han yang } \\
\text { Digunakan+Pinyin }\end{array}$ & $\begin{array}{l}\text { Contoh Kata dalam } \\
\text { Bahasa Mandarin }\end{array}$ & $\begin{array}{c}\text { Contoh Kata dalam } \\
\text { Bahasa Indonesia }\end{array}$ \\
\hline \multirow[b]{2}{*}{ /b/ } & \multirow[b]{2}{*}{ [b] } & \multirow[b]{2}{*}{ [p] } & 布 $b u$ & 阿布迪 (a-bu-di) & A $\underline{\text { bddi }}$ \\
\hline & & & 卜 $b u$ & $\begin{array}{l}\text { 伊卜努.哈迪（yi-bu-nu } \\
\text { ha-di) }\end{array}$ & Ibnu Hadi \\
\hline$/ \mathrm{d} /$ & [d] & {$[\mathrm{t}]$} & 德 $d e$ & 法德里 (fa-de-li) & Fadli \\
\hline \multirow{2}{*}{ /f/ } & \multirow{2}{*}[\mathrm{f}]{} & \multirow{2}{*}[\mathrm{f}]{} & 弗 $f u$ & $\begin{array}{l}\text { 博伊.拉弗利 (bo-yi |la-fu- } \\
\text { li) }\end{array}$ & Boy Rafli \\
\hline & & & 夫 $f u$ & 阿利夫 (a-li-fu) & Alif \\
\hline
\end{tabular}


Hasyim, R., \& Budianto, P., (2021). Analysis of Sound Translation of Indonesian Names in the Chinese Newspaper (Yinni Xingzhou Ribao). LITE: Jurnal Bahasa, Sastra, dan Budaya $17 \quad$ (2), $160-175$. https://doi.org/10.33633/lite.v17i2.5044

\begin{tabular}{|c|c|c|c|c|c|}
\hline Fonem & $\begin{array}{c}\text { Bunyi } \\
\text { dalam } \\
\text { Bahasa } \\
\text { Indonesia } \\
\end{array}$ & $\begin{array}{c}\text { Bunyi } \\
\text { dalam } \\
\text { Bahasa } \\
\text { Mandarin } \\
\end{array}$ & $\begin{array}{l}\text { Aksara Han yang } \\
\text { Digunakan+Pinyin }\end{array}$ & $\begin{array}{l}\text { Contoh Kata dalam } \\
\text { Bahasa Mandarin }\end{array}$ & $\begin{array}{c}\text { Contoh Kata dalam } \\
\text { Bahasa Indonesia }\end{array}$ \\
\hline$/ \mathrm{h} /$ & [h] & {$[\mathrm{x}]$} & 赫he & 瓦赫尤 (wa-he-you) & Wahyu \\
\hline$/ \mathrm{k} /$ & {$[\mathrm{k}]$} & [k'] & 克 ke & 埃利克 (ai-li-ke) & Erik \\
\hline \multirow[b]{2}{*}{$/ 1 /$} & \multirow{2}{*}{ [1] } & \multirow{2}{*}[\mathrm{r}]{} & 尔 $e r$ & 阿布杜尔 (a-bu-du-er) & Abdul \\
\hline & & & 耳 $e r$ & 法德耳 (fa-de-er) & Fadel \\
\hline$/ \mathrm{m} /$ & {$[\mathrm{m}]$} & {$[\mathrm{m}]$} & 姆 $m u$ & 纳迪姆 (na-di-mu) & Nadim \\
\hline \multirow{2}{*}{$/ \mathrm{p} /$} & \multirow{2}{*}{ [p] } & \multirow{2}{*}{ [p'] } & 帕 $p a$ & $\begin{array}{l}\text { 埃迪·帕拉勃沃 (ai-di |pa- } \\
\text { la-bo-wo) }\end{array}$ & Edi Prabowo \\
\hline & & & 普 $p u$ & $\begin{array}{l}\text { 安托·普拉波沃 (an-tuo| } \\
\text { pu-la-bo-wo) }\end{array}$ & Anto $\underline{\text { Prabowo }}$ \\
\hline /q/ & {$[\mathrm{k}]$} & {$\left[\mathrm{k}^{\prime}\right]$} & 克 $k e$ & 伊克巴耳 (yi-ke-ba-er) & Iqbal \\
\hline \multirow{3}{*}{$/ \mathrm{r} /$} & \multirow{3}{*}[\mathrm{r}]{} & \multirow{3}{*}[\mathrm{r}]{} & 尔 $e r$ & 阿尔雅 (a-er-ya) & Arya \\
\hline & & & 耳 $e r$ & $\begin{array}{l}\text { 阿卜都耳.哈林.伊斯甘达 } \\
\text { 尔 (a-bu-du-er | ha-lin | yi- } \\
\text { si-gan-da-er) }\end{array}$ & $\begin{array}{l}\text { Abutur Halin } \\
\text { Iskandar }\end{array}$ \\
\hline & & & 洱 er & $\begin{array}{l}\text { 普洱峇雅. 尤迪 (pu-er-ba- } \\
\text { ya| you-di) }\end{array}$ & Purbaya Yudhi \\
\hline \multirow[b]{2}{*}{$/ \mathrm{s} /$} & \multirow[b]{2}{*}[\mathrm{s}]{} & \multirow[b]{2}{*}{ [s] } & 斯 $s i$ & 达斯诺 (da-si-nuo) & Dasno \\
\hline & & & 丝 si & $\begin{array}{l}\text { 薇迪雅丝杜蒂 (wei-di-ya- } \\
\text { si-du-di) }\end{array}$ & Widyastuti \\
\hline$/ \mathrm{t} /$ & {$[\mathrm{t}]$} & {$\left[\mathrm{t}^{\prime}\right]$} & 特 te & 卢胡特 (lu-hu-te) & Luhut \\
\hline$|z|$ & {$[\mathrm{z}]$} & [ts] & 兹 $z i$ & 法伊兹 (fa-yi-zi) & Faiz \\
\hline
\end{tabular}

Pada bagian ini dibahas mengenai konsonan yang berdiri sendiri. Dikarenakan adanya keterbatasan aksara Han, konsonan ini ditransliterasikan terpisah atau sendiri. Konsonan ini dalam suatu suku kata tidak dapat ditransliterasikan bersama, oleh karena itu konsonan tersebut harus ditransliterasikan secara terpisah. Karena dalam bahasa Mandarin konsonan tidak bisa berdiri sendiri, saat ditransliterasikan ke dalam bahasa Mandarin akan ditambahkan fonem lain.

Hampir semua konsonan saat ditransliterasikan ke dalam bahasa Mandarin tidak mengalami perubahan dan mempertahankan penggunaan konsonan yang ada di bahasa Indonesia, walaupun saat dilafalkan menghasilkan bunyi yang berbeda. Beberapa konsonan saat ditransliterasikan ke dalam bahasa Mandarin mengalami perubahan. Hal ini dikarenakan tidak terdapat konsonan yang sama dalam bahasa Mandarin, sehingga digunakan konsonan dengan bunyi yang mendekati. Konsonan /v/ dan /f/ menghasilkan bunyi yang sama saat dilafalkan, sehingga saat ditransliterasikan tidak mengalami perubahan bunyi. Dalam bahasa Mandarin tidak terdapat konsonan / $/$ sehingga saat ditransliterasikan digunakan aksara Han dengan konsonan /f/. Pada saat nama Indonesia ditransliterasikan ke dalam bahasa Mandarin, konsonan /l/ dan /r/ menggunakan aksara Han dengan bunyi [er]. Konsonan /q/ pada bahasa Indonesia saat dilafalkan menghasilkan bunyi seperti konsonan /k/. Sementara, konsonan /f/, /s/, dan /m/ saat ditransliterasikan ke dalam bahasa Mandarin tidak mengalami perubahan bunyi. Contohnya Alif yang ditransliterasikan menjadi 阿利夫 (a-li-fu), fonem /f/ pada kedua bahasa memiliki bunyi yang sama yaitu [f].

Perubahan yang terjadi pada konsonan di atas disebabkan oleh dua hal. Pertama cara artikulasi, dan yang kedua, penerjemah berusaha mempertahankan konsonan pada bahasa sumber dengan menggunakan aksara Han yang memiliki konsonan yang sama dan mengesampingkan bunyi yang dihasilkan. 
Hasyim, R., \& Budianto, P., (2021). Analysis of Sound Translation of Indonesian Names in the Chinese Newspaper (Yinni Xingzhou Ribao). LITE: Jurnal Bahasa, Sastra, dan Budaya $17 \quad$ (2), $160-175$. https://doi.org/10.33633/lite.v17i2.5044

\subsubsection{Suku Kata}

Tabel 3: Tabel Suku Kata

\begin{tabular}{|c|c|c|c|}
\hline Suku kata & Aksara Han & $\begin{array}{c}\text { Pinyin+ Terjemahan } \\
\text { Bunyi }\end{array}$ & $\begin{array}{c}\text { Nama dalam Bahasa } \\
\text { Mandarin dan Indonesia }\end{array}$ \\
\hline an & 安 & an [an] & $\begin{array}{l}\text { 苏迪安 } \\
\text { (su-di-an) } \\
\text { Sudian }\end{array}$ \\
\hline In & 印 & yin [in] & $\begin{array}{l}\text { 德瓦玛德·印德拉 } \\
\text { (de-wa-ma-de | yin-de-la) } \\
\text { Dewamade Indra }\end{array}$ \\
\hline En & 恩 & en [ən] & $\begin{array}{l}\text { 恩杜斯·阿斯纳维 } \\
\text { (en-du-si | a-si-na-wei) } \\
\text { Entus Asnawi }\end{array}$ \\
\hline
\end{tabular}

Suku kata an, in dan en saat ditransliterasikan ke dalam bahasa Mandarin tidak mengalami perubahan bunyi. Sementara itu, suku kata in saat ditransliterasikan ke dalam bahasa Mandarin digunakan aksara Han dengan pinyin yin dan bunyi yang dihasilkan sama dengan bunyi [in] pada bahasa Indonesia.

Tabel 4: Tabel Suku Kata

\begin{tabular}{|c|c|c|c|}
\hline Suku kata & Aksara Han & $\begin{array}{c}\text { Pinyin+Terjemahan } \\
\text { Bunyi } \\
\end{array}$ & $\begin{array}{l}\text { Nama dalam Bahasa } \\
\text { Mandarin dan Indonesia }\end{array}$ \\
\hline \multirow{2}{*}{ ba } & 巴 & \multirow{2}{*}{$b a[\mathrm{pA}]$} & $\begin{array}{l}\text { 伊克巴耳 } \\
\text { (yi-ke-ba-er) } \\
\text { Iqbal }\end{array}$ \\
\hline & 峇 & & $\begin{array}{l}\text { 普尔峇 } \\
\text { (pu-er-ba) } \\
\text { Purba }\end{array}$ \\
\hline be & 贝 & bei $[\mathrm{peI}]$ & $\begin{array}{l}\text { 贝蒂 } \\
\text { (bei-di) } \\
\text { Beti }\end{array}$ \\
\hline \multirow{2}{*}{ bi } & 比 & \multirow{2}{*}{$b i[\mathrm{pi}]$} & $\begin{array}{l}\text { 比马·尤迪斯蒂拉 } \\
\text { (bi-ma | you-di-si-di-la) } \\
\text { Bima Yudhistira }\end{array}$ \\
\hline & 庇 & & $\begin{array}{l}\text { 埃马尔·伊宛·卢庇斯 } \\
\text { (ai-ma-er | yi-wan | lu-bi-si) } \\
\text { Elmar Iwan Lubis }\end{array}$ \\
\hline \multirow[b]{2}{*}{$\mathrm{bu}$} & 布 & \multirow[b]{2}{*}{$b u[\mathrm{pu}]$} & $\begin{array}{l}\text { 布迪·古纳迪 } \\
\text { (bu-di | gu-na-di) } \\
\text { Budi Gunadi }\end{array}$ \\
\hline & 卜 & & $\begin{array}{l}\text { 阿卜都耳.哈林·伊斯甘达尔 } \\
\text { (a-bu-du-er | ha-lin | yi-si-gan- } \\
\text { da-er) } \\
\text { Abutur Halin Iskandar }\end{array}$ \\
\hline \multirow{3}{*}{ bo } & 勃 & \multirow{3}{*}{$b o[\mathrm{po}]$} & $\begin{array}{l}\text { 埃迪·帕拉勃沃 } \\
\text { (ai-di | pa-la-bo-wo) } \\
\text { Edi Prabowo }\end{array}$ \\
\hline & 博 & & $\begin{array}{l}\text { 博伊.拉弗利 } \\
\text { (bo-yi | la-fu-li) } \\
\text { Boy Rafli }\end{array}$ \\
\hline & 波 & & $\begin{array}{l}\text { 波尼 } \\
\text { (bo-ni) } \\
\text { Boni }\end{array}$ \\
\hline
\end{tabular}


Hasyim, R., \& Budianto, P., (2021). Analysis of Sound Translation of Indonesian Names in the Chinese Newspaper (Yinni Xingzhou Ribao). LITE: Jurnal Bahasa, Sastra, dan Budaya $17 \quad$ (2), $160-175$. https://doi.org/10.33633/lite.v17i2.5044

\begin{tabular}{|c|c|c|c|}
\hline Suku kata & Aksara Han & $\begin{array}{c}\text { Pinyin+Terjemahan } \\
\text { Bunyi }\end{array}$ & $\begin{array}{l}\text { Nama dalam Bahasa } \\
\text { Mandarin dan Indonesia }\end{array}$ \\
\hline $\mathrm{ca}$ & 卡 & $k a\left[\mathrm{k}^{\prime} \mathrm{A}\right]$ & $\begin{array}{l}\text { 奥斯卡尔·普利马迪 } \\
\text { (ao-si-ka-er | pu-li-ma-di) } \\
\text { Oscar Primadi }\end{array}$ \\
\hline \multirow{2}{*}{$\mathrm{ca}$} & 札 & \multirow{2}{*}{$z h a$ [tsA] } & $\begin{array}{l}\text { 札里昂 } \\
\text { (zha-li-ang) } \\
\text { Cariang }\end{array}$ \\
\hline & 渣 & & $\begin{array}{l}\text { 贝洹卡尤 } \\
\text { (bei-zha-ka-you) } \\
\text { Beca Kayu }\end{array}$ \\
\hline \multirow{2}{*}{$\mathrm{da}$} & 达 & \multirow{2}{*}{$d a[\mathrm{tA}]$} & $\begin{array}{l}\text { 达斯诺 } \\
\text { (da-si-nuo) } \\
\text { Dasno }\end{array}$ \\
\hline & 妲 & & $\begin{array}{l}\text { 温妲 } \\
\text { (wen-da) } \\
\text { Winda }\end{array}$ \\
\hline \multirow{3}{*}{$\mathrm{di}$} & 迪 & \multirow{3}{*}{$d i[\mathrm{ti}]$} & $\begin{array}{l}\text { 布迪·古纳迪 } \\
\text { (bu-di | gu-na-di) } \\
\text { Budi Gunadi }\end{array}$ \\
\hline & 蒂 & & $\begin{array}{l}\text { 哈尔雅蒂 } \\
\text { (ha-er-ya-di) } \\
\text { Haryadi }\end{array}$ \\
\hline & 狄 & & $\begin{array}{l}\text { 狄迪 } \\
\text { (di-di) } \\
\text { Didi }\end{array}$ \\
\hline do & 多 & $d u o$ [tuo] & $\begin{array}{l}\text { 穆耳多科 } \\
\text { (mu-er-duo-ke) } \\
\text { Muldoko }\end{array}$ \\
\hline de & 德 & $d e[\mathrm{t} \gamma]$ & $\begin{array}{l}\text { 德瓦玛德.印德拉 } \\
\text { (de-wa-ma-de | yin-de-la) } \\
\text { Dewamade Indra }\end{array}$ \\
\hline $\mathrm{du}$ & 都 & $d u[\mathrm{tu}]$ & $\begin{array}{l}\text { 埃都耳.阿兹哈利 } \\
\text { (ai-du-er | a-zi-ha-li) } \\
\text { Aidul Azhari }\end{array}$ \\
\hline ga & 加 & jia [tcia] & $\begin{array}{l}\text { 法赫利·西勒加尔 } \\
\text { (fa-he-li | xi-lei-jia-er) } \\
\text { Fahri Siregar }\end{array}$ \\
\hline \multirow{2}{*}{$\mathrm{gu}$} & 古 & \multirow{2}{*}{$g u[\mathrm{ku}]$} & $\begin{array}{l}\text { 德古 } \\
\text { (de-gu) } \\
\text { Tegu }\end{array}$ \\
\hline & 姑 & & $\begin{array}{l}\text { 赫利·姑纳迪 } \\
\text { (he-li |gu-na-di) } \\
\text { Heri Gunardi }\end{array}$ \\
\hline ge & 格 & $g e[\mathrm{kr}]$ & $\begin{array}{l}\text { 本多克格德 } \\
\text { (ben-duo-ke-ge-de) } \\
\text { Pondok Gede }\end{array}$ \\
\hline \multirow{2}{*}{ ja } & 查 & cha [ts'A] & $\begin{array}{l}\text { 威查延托 } \\
\text { (wei-cha-yan-tuo) } \\
\text { Wijayanto }\end{array}$ \\
\hline & 雅 & $y a[\mathrm{iA}]$ & $\begin{array}{l}\text { 雅加达 } \\
\text { (ya-jia-da) } \\
\text { Jakarta }\end{array}$ \\
\hline ju & 朱 & $z h u[\mathrm{tsu}]$ & $\begin{array}{l}\text { 朱奈迪 } \\
\text { (zhu-nai-di) } \\
\text { Junaidi }\end{array}$ \\
\hline
\end{tabular}


Hasyim, R., \& Budianto, P., (2021). Analysis of Sound Translation of Indonesian Names in the Chinese Newspaper (Yinni Xingzhou Ribao). LITE: Jurnal Bahasa, Sastra, dan Budaya $17 \quad$ (2), $160-175$. https://doi.org/10.33633/lite.v17i2.5044

\begin{tabular}{|c|c|c|c|}
\hline Suku kata & Aksara Han & $\begin{array}{c}\text { Pinyin+Terjemahan } \\
\text { Bunyi } \\
\end{array}$ & $\begin{array}{l}\text { Nama dalam Bahasa } \\
\text { Mandarin dan Indonesia }\end{array}$ \\
\hline jo & 佐 & $z u o$ [tsuo] & $\begin{array}{l}\text { 佐科威 } \\
\text { (zuo-ke-wei) } \\
\underline{\text { Jokowi }}\end{array}$ \\
\hline $\mathrm{ra}$ & 拉 & la $[1 \mathrm{~A}]$ & $\begin{array}{l}\text { 赫林德拉 } \\
\text { (he-lin-de-la) } \\
\text { Herindra }\end{array}$ \\
\hline \multirow{4}{*}{ ri } & 利 & \multirow{4}{*}{$l i[\mathrm{li}]$} & $\begin{array}{l}\text { 埃利克 } \\
\text { (ai-li-ke) } \\
\text { Erik } \\
\end{array}$ \\
\hline & 里 & & $\begin{array}{l}\text { 约里斯 } \\
\text { (yue-li-si) } \\
\text { Yoris }\end{array}$ \\
\hline & 莉 & & $\begin{array}{l}\text { 莉斯玛 } \\
\text { (li-si-ma) } \\
\text { Risma } \\
\end{array}$ \\
\hline & 丽 & & $\begin{array}{l}\text { 丝丽·穆耳雅妮 } \\
\text { (si-li | mu-er-ya-ni) } \\
\text { Sri Mulyani }\end{array}$ \\
\hline $\mathrm{ru}$ & 鲁 & $l u[\mathrm{lu}]$ & $\begin{array}{l}\text { 赫鲁 } \\
\text { (he-lu) } \\
\text { Heru }\end{array}$ \\
\hline \multirow[b]{2}{*}{ re } & 列 & lie [lic] & $\begin{array}{l}\text { 列特诺·马尔苏迪 } \\
\text { (lie-te-nuo | ma-er-su-di) } \\
\text { Retno Marsudi }\end{array}$ \\
\hline & 勒 & lei [leI] & $\begin{array}{l}\text { 法赫利·西勒加尔 } \\
\text { (fa-he-li | xi-lei-jia-er) } \\
\text { Fahri Siregar }\end{array}$ \\
\hline ro & 罗 & lио [luo] & $\begin{array}{l}\text { 罗哈娜 } \\
\text { (luo-ha-na) } \\
\text { Rohana } \\
\end{array}$ \\
\hline vi & 维 & $w e i[\mathrm{ueI}]$ & $\begin{array}{l}\text { 苏克玛·维奥勒塔 } \\
\text { (su-ke-ma | wei-ao-lei-ta) } \\
\text { Sukma Violetta }\end{array}$ \\
\hline $\mathrm{za}$ & 萨 & $s a[\mathrm{sA}]$ & $\begin{array}{l}\text { 阿梵萨 } \\
\text { (a-fan-sa) } \\
\text { Avanza } \\
\end{array}$ \\
\hline $\mathrm{zu}$ & 祖 & $z u[\mathrm{tsu}]$ & $\begin{array}{l}\text { 阿姆祖利安 } \\
\text { (a-mu-zu-li-an) } \\
\text { Amzulian }\end{array}$ \\
\hline
\end{tabular}

Berdasarkan table 4, suku kata di atas merupakan suku kata yang menggunakan konsonan dengan bunyi yang tidak terdapat dalam bahasa Mandarin, contohnya adalah /b/, /c/, /d/, /g/, /j/, /r/ dan /z/. Karena dalam bahasa Mandarin tidak terdapat konsonan dengan bunyi tersebut, penerjemah mencari aksara Han yang penulisan pinyinnya sesuai dengan bahasa Indonesia atau mencari bunyi yang mendekati dan mengabaikan perbedaan bunyi yang dihasilkan ketika ditransliterasikan ke dalam bahasa Mandarin. Perbedaan bunyi dapat terjadi karena bunyi konsonan tersebut dalam bahasa Indonesia dan dalam bahasa Mandarin berbeda. Contohnya adalah pada kata Purba yang ditransliterasikan menjadi 普尔荅 (pu-er-ba), fonem /b/ dalam bahasa Mandarin memiliki bunyi [p] dan hal ini membuktikan bahwa bunyi fonem /b/ pada kedua bahasa berbeda.

Fonem /r/ berubah menjadi /l/ ketika ditransliterasikan ke dalam bahasa Mandarin dikarenakan bunyi /r/ yang dihasilkan dalam bahasa Indonesia dengan bunyi konsonan /r/ yang ada dalam bahasa 
Hasyim, R., \& Budianto, P., (2021). Analysis of Sound Translation of Indonesian Names in the Chinese Newspaper (Yinni Xingzhou Ribao). LITE: Jurnal Bahasa, Sastra, dan Budaya $17 \quad$ (2), $160-175$. https://doi.org/10.33633/lite.v17i2.5044

Mandarin berbeda. Dalam bahasa Mandarin konsonan /r/ bukan konsonan getar seperti yang terdapat dalam bahasa Indonesia. Contohnya adalah pada kata Heru yang ditransliterasikan menjadi 赫鲁 (helu), fonem /r/ berubah menjadi /l/ saat ditransliterasikan karena bunyi fonem /r/ yang berbeda pada kedua bahasa.

Fonem /c/ saat ditransliterasikan ke dalam bahasa Mandarin menggunakan aksara Han dengan konsonan retrofleks /zh/ dan bunyi yang dihasilkan antara kosonan /c/ dalam bahasa Indonesia dengan konsonan retrofleks /zh/ dalam bahasa Mandarin menghasilkan bunyi yang mirip. Dalam bahasa Mandarin, [zh] diucapkan seperti [ce] pada kata "cepat" (Yasin, 2018: 7). Oleh karena itu, saat fonem konsonan /c/ ditransliterasikan ke dalam bahasa Mandarin digunakan aksara Han /zh/.

Tabel 5: Tabel Suku Kata

\begin{tabular}{|c|c|c|c|}
\hline Suku kata & Aksara Han & $\begin{array}{c}\text { Pinyin+Terjemahan } \\
\text { Bunyi } \\
\end{array}$ & $\begin{array}{l}\text { Nama dalam Bahasa } \\
\text { Mandarin dan Indonesia }\end{array}$ \\
\hline $\mathrm{ka}$ & 卡 & $k a\left[\mathrm{k}^{\prime} \mathrm{A}\right]$ & $\begin{array}{l}\text { 丽丝卡 } \\
\text { (li-si-ka) } \\
\text { Riska }\end{array}$ \\
\hline \multirow{2}{*}{$\mathrm{ku}$} & 古 & $g u[\mathrm{ku}]$ & $\begin{array}{l}\text { 维古 } \\
\text { (wei-gu) } \\
\text { Wiku }\end{array}$ \\
\hline & 库 & $k u\left[\mathrm{k}^{\prime} \mathrm{u}\right]$ & $\begin{array}{l}\text { 库塔海滩 } \\
\text { (ku-ta haitan) } \\
\text { Pantai Kuta }\end{array}$ \\
\hline ke & 格 & $g e[\mathrm{kr}]$ & $\begin{array}{l}\text { 格峇约蓝峇鲁 } \\
\text { (ge-ba-yue-lan-ba-lu) } \\
\text { Kebayoran Baru }\end{array}$ \\
\hline ko & 科 & $k e\left[\mathrm{k}^{\prime} \gamma\right]$ & $\begin{array}{l}\text { 佐科威 } \\
\text { (zuo-ke-wei) } \\
\text { Jokowi }\end{array}$ \\
\hline $\mathrm{pa}$ & 帕 & $p a$ [p'A] & $\begin{array}{l}\text { 帕哈拉·曼苏利 } \\
\text { (pa-ha-la | man-su-li) } \\
\text { Pahala Mansury }\end{array}$ \\
\hline \multirow{3}{*}{ pi } & 毕 & \multirow{3}{*}{$b i[\mathrm{pi}]$} & $\begin{array}{l}\text { 乌毕 } \\
\text { (wu-bi) } \\
\text { Upik }\end{array}$ \\
\hline & 比 & & $\begin{array}{l}\text { 布卢比都 } \\
\text { (bu-lu-bi-du) } \\
\text { Bulupitu }\end{array}$ \\
\hline & 彼 & & $\begin{array}{l}\text { 彼得·阿卜都拉 } \\
\text { (bi-de | a-bu-du-la) } \\
\text { Piter Abdullah }\end{array}$ \\
\hline \multirow[b]{2}{*}{$\mathrm{pu}$} & 普 & $\mathrm{pu}\left[\mathrm{p}^{\prime} \mathrm{u}\right]$ & $\begin{array}{l}\text { 普特拉 } \\
\text { (pu-te-la) } \\
\text { Putra }\end{array}$ \\
\hline & 布 & $b u[\mathrm{pu}]$ & $\begin{array}{l}\text { 阿立夫·布尔纳玛·奥克托拉 } \\
\text { (a-li-fu | bu-er-na-ma | ao-ke- } \\
\text { tuo-la) } \\
\text { Alif Purnama Oktora }\end{array}$ \\
\hline po & 博 & $b o[\mathrm{po}]$ & $\begin{array}{l}\text { 德博 } \\
\text { (de-bo) } \\
\text { Depok }\end{array}$ \\
\hline pe & 佩 & pei [p'eI] & $\begin{array}{l}\text { 佩妮·卢姬托 } \\
\text { (pei-ni |lu-ji-tuo) } \\
\text { Penny Lukito }\end{array}$ \\
\hline
\end{tabular}


Hasyim, R., \& Budianto, P., (2021). Analysis of Sound Translation of Indonesian Names in the Chinese Newspaper (Yinni Xingzhou Ribao). LITE: Jurnal Bahasa, Sastra, dan Budaya $17 \quad$ (2), $160-175$. https://doi.org/10.33633/lite.v17i2.5044

\begin{tabular}{|c|c|c|c|}
\hline Suku kata & Aksara Han & $\begin{array}{c}\text { Pinyin+Terjemahan } \\
\text { Bunyi } \\
\end{array}$ & $\begin{array}{l}\text { Nama dalam Bahasa } \\
\text { Mandarin dan Indonesia } \\
\end{array}$ \\
\hline \multirow{3}{*}{ ta } & 达 & \multirow{2}{*}{$d a[\mathrm{tA}]$} & $\begin{array}{l}\text { 苏达尔诺 } \\
\text { (su-da-er-nuo) } \\
\text { Sutarno }\end{array}$ \\
\hline & 打 & & $\begin{array}{l}\text { 打峇南 } \\
\text { (da-ba-nan) } \\
\text { Tabanan } \\
\end{array}$ \\
\hline & 塔 & $\operatorname{ta}\left[\mathrm{t}^{\prime} \mathrm{A}\right]$ & $\begin{array}{l}\text { 塔尔曼 } \\
\text { (ta-er-man) } \\
\text { Tarman } \\
\end{array}$ \\
\hline \multirow{3}{*}{ te } & 特 & $t e\left[\mathrm{t}^{\prime} \gamma\right]$ & $\begin{array}{l}\text { 苏特佐 } \\
\text { (su-te-zuo) } \\
\text { Sutejo }\end{array}$ \\
\hline & 德 & \multirow{2}{*}{$d e[\mathrm{tr}]$} & $\begin{array}{l}\text { 德古 } \\
\text { (de-gu) } \\
\text { Tegu }\end{array}$ \\
\hline & 得 & & $\begin{array}{l}\text { 彼得.阿卜都拉 } \\
\text { (bi-de | a-bu-du-la) } \\
\text { Piter Abdullah }\end{array}$ \\
\hline to & 托 & tuo [t'uo] & $\begin{array}{l}\text { 托尼·埃卡 } \\
\text { (tuo-ni | ai-ka) } \\
\text { Toni Eka }\end{array}$ \\
\hline \multirow{2}{*}{$\mathrm{ti}$} & 迪 & \multirow{2}{*}{$d i[\mathrm{ti}]$} & $\begin{array}{l}\text { 法迪玛纳 } \\
\text { (fa-di-ma-na) } \\
\text { Fatimana }\end{array}$ \\
\hline & 蒂 & & $\begin{array}{l}\text { 穆克蒂·法查尔 } \\
\text { (mu-ke-di | fa-cha-er) } \\
\text { Mukti Fajar }\end{array}$ \\
\hline \multirow{3}{*}{ tu } & 杜 & \multirow{2}{*}{$d u[\mathrm{tu}]$} & $\begin{array}{l}\text { 杜蒂 } \\
\text { (du-di) } \\
\text { Tuti }\end{array}$ \\
\hline & 都 & & $\begin{array}{l}\text { 布卢比都 } \\
\text { (bu-lu-bi-du) } \\
\text { Bulupitu }\end{array}$ \\
\hline & 图 & $t u\left[\mathrm{t}^{\prime} \mathrm{u}\right]$ & $\begin{array}{l}\text { 图卢斯·阿峇迪 } \\
\text { (tu-lu-si | a-ba-di) } \\
\text { Tulus Abadi }\end{array}$ \\
\hline
\end{tabular}

Tabel merupakan suku kata dengan penggunaan konsonan yang dalam bahasa Mandarin dan bahasa Indonesia memiliki bunyi yang sama, namun dengan penulisan pinyin yang berbeda yaitu konsonan /k/, /p/, dan /t/. Konsonan tersebut dalam bahasa Mandarin merupakan fonem /g/, /b/, dan /d/. Oleh karena itu, saat suku kata dengan konsonan tersebut ditransliterasikan ke dalam bahasa Mandarin ada yang mengalami perubahan konsonan untuk menyesuaikan dengan bunyi yang dihasilkan dalam bahasa Mandarin. Selain itu, ada yang dicari penulisan pinyinnya yang sama dengan bahasa Indonesia dan mengesampingkan perubahan bunyi yang terjadi, dan tidak peduli apakah konsonan tersebut dalam bahasa Mandarin menghasilkan bunyi aspirasi. Contohnya pada kata Tarman yang ditransliterasikan menjadi 塔尔曼(ta-er-man), fonem /t/ dalam bahasa Mandarin dibaca beraspirasi.

Tabel 6: Tabel Suku Kata

\begin{tabular}{cccl}
\hline Suku kata & Aksara Han & $\begin{array}{c}\text { Pinyin+Terjemahan } \\
\text { Bunyi }\end{array}$ & $\begin{array}{l}\text { Nama } \\
\text { Mandarin dan Indonesia }\end{array}$ \\
\hline $\mathrm{fa}$ & 法 & $f a[\mathrm{fA}]$ & 穆斯塔法 \\
\hline
\end{tabular}


Hasyim, R., \& Budianto, P., (2021). Analysis of Sound Translation of Indonesian Names in the Chinese Newspaper (Yinni Xingzhou Ribao). LITE: Jurnal Bahasa, Sastra, dan Budaya $17 \quad$ (2), $160-175$. https://doi.org/10.33633/lite.v17i2.5044

\begin{tabular}{|c|c|c|c|}
\hline Suku kata & Aksara Han & $\begin{array}{c}\text { Pinyin+Terjemahan } \\
\text { Bunyi }\end{array}$ & $\begin{array}{l}\text { Nama dalam Bahasa } \\
\text { Mandarin dan Indonesia }\end{array}$ \\
\hline & & & $\begin{array}{l}\text { (mu-si-ta-fa) } \\
\text { Mustafa }\end{array}$ \\
\hline fi & \multirow{2}{*}{ 菲 } & \multirow{2}{*}{$f e i[\mathrm{fe} I]$} & $\begin{array}{l}\text { 卢特菲 } \\
\text { (lu-te-fei) } \\
\text { Lutfi }\end{array}$ \\
\hline fe & & & $\begin{array}{l}\text { 菲尔迪 } \\
\text { (fei-er-di) } \\
\text { Ferdi } \\
\end{array}$ \\
\hline $\mathrm{fu}$ & 福 & $f u[\mathrm{fu}]$ & $\begin{array}{l}\text { 马赫福德 } \\
\text { (ma-he-fu-de) } \\
\text { Mahfud }\end{array}$ \\
\hline ha & 哈 & $h a[\mathrm{xA}]$ & $\begin{array}{l}\text { 苏哈尔诺 } \\
\text { (su-ha-er-nuo) } \\
\text { Suharno }\end{array}$ \\
\hline he & 赫 & $h e[\mathrm{xr}]$ & $\begin{array}{l}\text { 赫鲁 } \\
\text { (he-lu) } \\
\text { Heru }\end{array}$ \\
\hline hu & 胡 & $h u[\mathrm{xu}]$ & $\begin{array}{l}\text { 卢胡特 } \\
\text { (lu-hu-te) } \\
\text { Luhut }\end{array}$ \\
\hline la & 拉 & la $[1 \mathrm{~A}]$ & $\begin{array}{l}\text { 毛拉纳·慕卡洛姆 } \\
\text { (mao-la-na | mu-ka-luo-mu) } \\
\text { Maulana Mukarom }\end{array}$ \\
\hline \multirow{4}{*}{ li } & 利 & \multirow{4}{*}{$l i[\mathrm{li}]$} & $\begin{array}{l}\text { 博伊.拉弗利 } \\
\text { (bo-yi | la-fu-li) } \\
\text { Boy Rafli }\end{array}$ \\
\hline & 里 & & $\begin{array}{l}\text { 法德里 } \\
\text { (fa-de-li) } \\
\text { Fadli }\end{array}$ \\
\hline & 莉 & & $\begin{array}{l}\text { 阿莉雅 } \\
\text { (a-li-ya) } \\
\text { Alia }\end{array}$ \\
\hline & 立 & & $\begin{array}{l}\text { 阿立夫·布尔纳玛·奥克托拉 } \\
\text { (a-li-fu | bu-er-na-ma | ao-ke- } \\
\text { tuo-la) } \\
\text { Alif Purnama Oktora }\end{array}$ \\
\hline \multirow{2}{*}{ lu } & 卢 & \multirow{2}{*}{$l u[l \mathrm{u}]$} & $\begin{array}{l}\text { 卢胡特 } \\
\text { (lu-hu-te) } \\
\text { Luhut }\end{array}$ \\
\hline & 露 & & $\begin{array}{l}\text { 巴露 } \\
\text { (ba-lu) } \\
\text { Palu }\end{array}$ \\
\hline \multirow{2}{*}{ lo } & 洛 & \multirow{2}{*}{ lиo [luo] } & $\begin{array}{l}\text { 苏西洛 } \\
\text { (su-xi-luo) } \\
\text { Susilo }\end{array}$ \\
\hline & 罗 & & $\begin{array}{l}\text { 梭罗 } \\
\text { (suo-luo) } \\
\text { Solo }\end{array}$ \\
\hline le & 勒 & lei [leI] & $\begin{array}{l}\text { 苏克玛·维奥勒塔 } \\
\text { (su-ke-ma | wei-ao-lei-ta) } \\
\text { Sukma Violetta }\end{array}$ \\
\hline $\mathrm{ma}$ & 玛 & $m a[\mathrm{~mA}]$ & $\begin{array}{l}\text { 萨利玛 } \\
\text { (sa-li-ma) } \\
\text { Salima }\end{array}$ \\
\hline
\end{tabular}


Hasyim, R., \& Budianto, P., (2021). Analysis of Sound Translation of Indonesian Names in the Chinese Newspaper (Yinni Xingzhou Ribao). LITE: Jurnal Bahasa, Sastra, dan Budaya $17 \quad$ (2), $160-175$. https://doi.org/10.33633/lite.v17i2.5044

\begin{tabular}{|c|c|c|c|}
\hline Suku kata & Aksara Han & $\begin{array}{c}\text { Pinyin+Terjemahan } \\
\text { Bunyi } \\
\end{array}$ & $\begin{array}{l}\text { Nama dalam Bahasa } \\
\text { Mandarin dan Indonesia }\end{array}$ \\
\hline & 马 & & $\begin{array}{l}\text { 马赫福德 } \\
\text { (ma-he-fu-de) } \\
\text { Mahfud }\end{array}$ \\
\hline \multirow{2}{*}{$\mathrm{mu}$} & 穆 & \multirow{2}{*}{$m u[\mathrm{mu}]$} & $\begin{array}{l}\text { 丝丽·穆耳雅妮 } \\
\text { (si-li | mu-er-ya-ni) } \\
\text { Sri Mulyani }\end{array}$ \\
\hline & 慕 & & $\begin{array}{l}\text { 埃迪·慕尔雅纳 } \\
\text { (ai-di | mu-er-ya-na) } \\
\text { Edi Mulyana }\end{array}$ \\
\hline $\mathrm{mi}$ & 米 & $m i[\mathrm{mi}]$ & $\begin{array}{l}\text { 乌米 } \\
\text { (wu-mi) } \\
\text { Umi }\end{array}$ \\
\hline me & 梅 & mei $[\mathrm{meI}]$ & $\begin{array}{l}\text { 梅琳达 } \\
\text { (mei-lin-da) } \\
\text { Melinda }\end{array}$ \\
\hline \multirow{2}{*}{ mo } & 莫 & \multirow{2}{*}{$m o[\mathrm{mo}]$} & $\begin{array}{l}\text { 苏尔约帕拉托莫 } \\
\text { (su-er-yue-pa-la-tuo-mo) } \\
\text { Suryopratomo }\end{array}$ \\
\hline & 摩 & & $\begin{array}{l}\text { 帕拉摩诺 } \\
\text { (pa-la-mo-nuo) } \\
\text { Pramono }\end{array}$ \\
\hline \multirow{2}{*}{ na } & 娜 & \multirow{2}{*}{$n a[\mathrm{nA}]$} & $\begin{array}{l}\text { 罗哈娜 } \\
\text { (luo-ha-na) } \\
\text { Rohana } \\
\end{array}$ \\
\hline & 纳 & & $\begin{array}{l}\text { 布迪·古纳迪 } \\
\text { (bu-di | gu-na-di) } \\
\text { Budi Gunadi }\end{array}$ \\
\hline \multirow{2}{*}{ ni } & 尼 & \multirow{2}{*}{$n i[\mathrm{ni}]$} & $\begin{array}{l}\text { 多尼 } \\
\text { (duo-ni) } \\
\text { Doni } \\
\end{array}$ \\
\hline & 妮 & & $\begin{array}{l}\text { 苏米妮 } \\
\text { (su-mi-ni) } \\
\text { Sumini }\end{array}$ \\
\hline nu & 努 & $n u[\mathrm{nu}]$ & $\begin{array}{l}\text { 伊卜努·哈迪 } \\
\text { (yi-bu-nu | ha-di) } \\
\text { Ibnu Hadi }\end{array}$ \\
\hline no & 诺 & пио [nuo] & $\begin{array}{l}\text { 达斯诺 } \\
\text { (da-si-nuo) } \\
\text { Dasno }\end{array}$ \\
\hline sa & 萨 & $s a[\mathrm{sA}]$ & $\begin{array}{l}\text { 萨利玛 } \\
\text { (sa-li-ma) } \\
\text { Salima }\end{array}$ \\
\hline su & 苏 & $s u[\mathrm{su}]$ & $\begin{array}{l}\text { 峇苏基 } \\
\text { (ba-su-ji) } \\
\text { Basuki }\end{array}$ \\
\hline so & 梭 & suo [suo] & $\begin{array}{l}\text { 卡尔梭 } \\
\text { (ka-er-suo) } \\
\text { Karso }\end{array}$ \\
\hline \multirow{2}{*}{ wa } & 瓦 & \multirow{2}{*}{$w \mathrm{a}[\mathrm{uA}]$} & $\begin{array}{l}\text { 瓦赫尤 } \\
\text { (wa-he-you) } \\
\text { Wahyu }\end{array}$ \\
\hline & 娃 & & $\begin{array}{l}\text { 妮尔娃拉·哈尔延托 } \\
\text { (ni-er-wa-la | ha-er-yan-tuo) } \\
\text { Nirwala Haryanto }\end{array}$ \\
\hline
\end{tabular}


Hasyim, R., \& Budianto, P., (2021). Analysis of Sound Translation of Indonesian Names in the Chinese Newspaper (Yinni Xingzhou Ribao). LITE: Jurnal Bahasa, Sastra, dan Budaya $17 \quad$ (2), $160-175$. https://doi.org/10.33633/lite.v17i2.5044

\begin{tabular}{|c|c|c|c|}
\hline Suku kata & Aksara Han & $\begin{array}{c}\text { Pinyin+Terjemahan } \\
\text { Bunyi } \\
\end{array}$ & $\begin{array}{l}\text { Nama dalam Bahasa } \\
\text { Mandarin dan Indonesia }\end{array}$ \\
\hline & 哇 & & $\begin{array}{l}\text { 普哇加达 } \\
\text { (pu-wa-jia-da) } \\
\text { Purwakarta }\end{array}$ \\
\hline \multirow{3}{*}{ wi } & 威 & \multirow{3}{*}{ wei [uer] } & $\begin{array}{l}\text { 佐科威 } \\
\text { (zuo-ke-wei) } \\
\text { Jokowi }\end{array}$ \\
\hline & 维 & & $\begin{array}{l}\text { 维古 } \\
\text { (wei-gu) } \\
\text { Wiku } \\
\end{array}$ \\
\hline & 微 & & $\begin{array}{l}\text { 薇迪雅丝杜蒂 } \\
\text { (wei-di-ya-si-du-di) } \\
\text { Widyastuti }\end{array}$ \\
\hline we & 威 & wei [uer] & $\begin{array}{l}\text { 阿尼斯·峇斯威丹 } \\
\text { (a-ni-si | ba-si-wei-dan) } \\
\text { Anies Baswedan }\end{array}$ \\
\hline wo & 沃 & wo [uo] & $\begin{array}{l}\text { 尤沃诺 } \\
\text { (you-wo-nuo) } \\
\text { Yuwono }\end{array}$ \\
\hline ya & 雅 & $y a[\mathrm{iA}]$ & $\begin{array}{l}\text { 阿尔雅 } \\
\text { (a-er-ya) } \\
\text { Arya }\end{array}$ \\
\hline \multirow{2}{*}{$\mathrm{yu}$} & 友 & \multirow{2}{*}{ уои [iәઇ] } & $\begin{array}{l}\text { 卡友玛尼斯 } \\
\text { (ka-you-ma-ni-si) } \\
\text { Kayu manis }\end{array}$ \\
\hline & 尤 & & $\begin{array}{l}\text { 尤沃诺 } \\
\text { (you-wo-nuo) } \\
\text { Yuwono } \\
\end{array}$ \\
\hline yo & 约 & yao [iav] & $\begin{array}{l}\text { 约里斯 } \\
\text { (yue-li-si) } \\
\text { Yoris } \\
\end{array}$ \\
\hline ye & 耶 & $y e[\mathrm{i} \varepsilon]$ & $\begin{array}{l}\text { 万玛·耶蒂 } \\
\text { (wan-ma | ye-di) } \\
\text { Wanma Yeti }\end{array}$ \\
\hline
\end{tabular}

Tabel merupakan suku kata yang menggunakan konsonan dengan bunyi yang sama atau mirip pada kedua bahasa. Perbedaan yang terjadi hanya dikarenakan oleh fonem vokal yang terdapat pada suku kata tersebut. Perubahan yang diakibatkan oleh perubahan fonem vokal pada suku kata tersebut tidak begitu memengaruhi bunyi, karena bunyi yang dihasilkan saat suku kata tersebut ditransliterasikan ke dalam bahasa Mandarin tetap mirip.

Berdasarkan data terdapat suku kata yang menggunakan konsonan /w/ dan /y/. Konsonan /w/ dan /y/ dalam bahasa Indonesia saat ditransliterasikan ke dalam bahasa Mandarin menghasilkan bunyi [u] dan [i]. Dalam bahasa Mandarin tidak ada konsonan /w/ dan /y/ dan konsonan /w/ dan /y/ hanya digunakan untuk menghindari kebingungan saat penulisan pinyin. Meskipun demikian, bunyi yang dihasilkan tetap sama dengan konsonan /w/ dan /y/ yang terdapat pada bahasa Indonesia. Contohnya pada kata Wahyu yang ditransliterasikan menjadi 瓦赫尤 (wa-he-you), walaupun fonem /w/ menghasilkan bunyi $[\mathrm{u}$ ], namun bunyi yang dihasilkan tetap sama dengan fonem /w/ dalam bahasa Indonesia.

Dalam bahasa Indonesia konsonan /w/ saat ditransliterasikan ke dalam bahasa Mandarin menggunakan aksara Han dengan konsonan yang sama yaitu /w/, namun dalam bahasa Mandarin bunyi konsonan /w/ dituliskan [u]. Hal ini dikarenakan dalam bahasa Mandarin konsonan /w/ 
Hasyim, R., \& Budianto, P., (2021). Analysis of Sound Translation of Indonesian Names in the Chinese Newspaper (Yinni Xingzhou Ribao). LITE: Jurnal Bahasa, Sastra, dan Budaya 17 (2), 160-175. https://doi.org/10.33633/lite.v17i2.5044

sebenarnya adalah bunyi dari fonem /u/. Dalam bahasa Mandarin jika aksara Han dimulai dengan fonem vokal /u/ dan di belakang fonem /u/ diikuti dengan fonem vokal lain, fonem /u/ akan berubah menjadi /w/. Apabila setelah fonem /u/ tidak terdapat fonem vokal lain, maka di depan fonem /u/ akan ditambahkan fonem /w/ (Song Haiyan, 2013).

Sama halnya seperti konsonan /w/ yang merupakan fonem /u/, konsonan /y/ dalam bahasa Mandarin sebenarnya merupakan fonem /i/. Dalam bahasa Mandarin jika aksara Han dimulai dengan fonem vokal /i/ dan di belakang fonem /i/ diikuti dengan fonem vokal lain, fonem /i/ akan berubah menjadi /y/. Apabila setelah fonem /i/ tidak ada fonem vokal lain maka di depan fonem /i/ akan ditambahkan fonem /y/ (Song Haiyan, 2013).

Konsonan /h/ saat ditransliterasikan ke dalam bahasa Mandarin digunakan aksara Han dengan konsonan /h/ dengan bunyi [x]. Walaupun memiliki penulisan bunyi yang berbeda dengan konsonan /h/ dalam bahasa Indonesia, keduanya menghasilkan bunyi yang mirip. Konsonan $/ \mathrm{h} / \mathrm{dalam}$ bahasa Indonesia memiliki dua cara pengujaran yaitu $[\mathrm{h}]$ dan $[\mathrm{h}]$. Cara pengujaran $/ \mathrm{h} /$ yang pertama yang menghasilkan bunyi $[\mathrm{h}]$ dalam bahasa Indonesia mirip dengan bunyi konsonan $/ \mathrm{h} / \mathrm{dalam}$ bahasa Mandarin, contohnya seperti pada kata "hari" [hari], sedangkan $/ \mathrm{h} /$ yang menghasilkan bunyi [ $\mathrm{h}$ ] adalah yang ketika diujarkan ringan hampir tidak terdengar, contohnya seperti pada kata "lihat" [liat] (Karsono, 2014).

Adanya asimetri jumlah suku kata dan metode kombinasi suku kata dalam bahasa asing dan bahasa Mandarin menyebabkan perlunya pergantian fonem ketika fonem yang sesuai tidak ditemukan dalam bahasa Mandarin (Liu Xiangqing, 2019: 112-117).

\section{Simpulan}

Dari penelitian yang telah dilakukan, didapatkan simpulan bahwa nama Indonesia yang ditransliterasikan ke dalam bahasa Mandarin merupakan penerjemahan bunyi dengan strategi menyesuaikan (adaptation). Vokal saat ditransliterasikan menghasilkan bunyi yang sama dengan bunyi bahasa Mandarin, kecuali fonem /o/ dan /e/ yang berubah menjadi [ao] dan [ai]. Konsonan yang berdiri sendiri saat ditransliterasikan ke dalam bahasa Mandarin menggunakan aksara Han dengan konsonan yang sama seperti yang digunakan pada bahasa Indonesia.

Penerjemahan bunyi nama Indonesia ke dalam bahasa Mandarin dilihat dari sisi suku kata, yaitu (a) jika tidak terdapat suku kata dengan fonem konsonan yang bunyinya sama dalam bahasa Mandarin, dicari aksara Han yang memiliki penulisan pinyin yang sesuai dengan fonem konsonan dalam bahasa Indonesia atau bunyi yang mendekati, (b) jika terdapat suku kata dengan fonem konsonan yang memiliki bunyi sama namun dengan penulisan pinyin yang berbeda dalam bahasa Mandarin, saat ditransliterasikan dapat dicari aksara Han dengan penulisan pinyin yang sama dengan fonem konsonan dalam bahasa Indonesia atau disesuaikan dengan bunyi yang dihasilkan dalam bahasa Mandarin, (c) beberapa suku kata menggunakan fonem konsonan dengan bunyi yang sama atau mirip dengan penulisan yang sama pada kedua bahasa.

\section{Referensi}

Chen Shunyi. (2014). Xiandai Hanyu Zhong Wailaici De Bentuhua Ji Ganyu Celüe. Journal of Changsha University of Science \& Technology (Social Science), 29 (5), 93-96. Diakses dari https://www.cnki.com.cn/Article/CJFDTOTAL-CSSC201405018.htm

Hermans, T. (1988). On translating proper names, with reference to De Witte and Max Havelaar. In M. J. Wintle (ed.) Modern Dutch Studies. Essays in Honour of Professor Peter King on the Occasion of his Retirement. Bloomsbury Academic 2015. 
Hasyim, R., \& Budianto, P., (2021). Analysis of Sound Translation of Indonesian Names in the Chinese Newspaper (Yinni Xingzhou Ribao). LITE: Jurnal Bahasa, Sastra, dan Budaya 17 (2), 160-175. https://doi.org/10.33633/lite.v17i2.5044

Karsono, M. O. F. (2014). Pengantar Linguistik Bahasa Tionghoa. CV. Perwira Media Nusantara. Diakses dari http://repository.petra.ac.id/16809/

Lian, J., \& Dai, W. (2012). Waiguo Guoming Hanyu Yinyi Yu Sikao. Journal of Southwest Agricultural University (Social Science Edition), 10 (11), 132-136. Diakses dari https://www.cnki.com.cn/Article/CJFDTOTAL-SCSM201211036.htm

Liu Xiangqing. (2013). Yuyan Jiechu Yu Hanyu Yinyi Ci De Xingcheng Yu Bianhua. Journal of Hunan First Normal University, 13 (3), 87-90,114. Diakses dari https://www.cnki.com.cn/Article/CJFDTOTAL-DYHN201303023.htm

Liu Xiangqing. (2019). Wailaici Yinyi Hanhua Yanjiu. Foreign Language and Literature (Bimonthly), 35 (2), 112-117. Diakses dari https://www.cnki.com.cn/Article/CJFDTOTALSCWY201902018.htm

Liu Xiangqing. (2019). Lun Hanyu Yinyi Jiqi Tedian. Journal of Hunan First Normal University, 19 (6), 92-96. Diakses dari http://cnki.com.cn/Article/CJFDTOTAL-DYHN201906018.htm

Liu Xiangqing. (2021). Lun Yinyi Han Du Jiqi Wenhua Jiazhi. Shanghai Journal of Translators, (1), $23-27$. Diakses dari http://gb.oversea.cnki.net/KCMS/detail/detail.aspx?filename=SHKF202101006\&dbcode=CJF D\&dbname $=$ CJFDTEMP

Simanto, S. (2013). Penerjemahan Bunyi Nama Laki-laki Orang Indonesia ke dalam Bahasa Mandarin Berdasarkan Surat Kabar 'Qiandao’ Edisi September 2011 sampai Januari 2012. Skripsi Universitas Kristen Maranatha. Diakses dari http://repository.maranatha.edu/10772/

Song Haiyan. (2013). 《Yuyin Yu Yuyin Jiaoxue》. Beijing: Higher Education Press.

Suhardi, Pratomo Widodo, \& Teguh Setiawan. (2019). Ekuivalensi Nama Diri dalam Bahasa Asing ke dalam Bahasa Indonesia. LITERA, 18 (1), 1-16. Diakses dari https://journal.uny.ac.id/index.php/litera/article/view/23105

Wu Liquan. (2018). Hanyu Wailaici Yinyi Jiqi Yinyi Wenhua Xinli Tanjiu, 11, 50-61. Diakses dari http://cnki.com.cn/Article/CJFDTotal-YYXT201802015.htm

Wu Liquan. (2018). "Xin Da Ya" Yu Waiguo Renming De Hanyu Yinyi, 7-15. Diakses dari https://www.cnki.com.cn/Article/CJFDTOTAL-CJXS201901010.htm

Yasin, R. A. (2018). 1 Jam Mahir Berbahasa Mandarin. Jogjakarta: Elmatera.

Zhang Yu. (2011). Xiandai Hanyu Yinyi Diming Yongzi Yanjiu. Shandong Normal University Thesis. Diakses dari https://cdmd.cnki.com.cn/Article/CDMD-10445-1011080796.htm

Zhu, G., \& Liu, X. (2020). Lun Hanyu Yinyi De Buzhou Yu Yiyin Hanzi Xuanze. Chinese Science \& Technology Translators Journal, 33 (4), 39-42. Diakses dari https://www.cnki.com.cn/Article/CJFDTOTAL-KJFY202004012.htm 